\title{
Solution Focused Brief Therapy untuk Meningkatkan Rasa Percaya Diri Remaja
}

\author{
Devi Eryanti \\ Program Studi Bimbingan Konseling Islam, Fakultas Ilmu Dakwah dan Komunikasi, \\ UIN Sunan Gunung Djati Bandung \\ devieryanti19@gmail.com
}

\begin{abstract}
Abstrak
Percaya diri dibutuhan oleh setiap individu, termasuk remaja. Rasa percaya diri yang dimiliki remaja akan mempengaruhi pengembangan potensi yang dimilikinya apabila remaja tersebut memiliki rasa percaya diri yang rendah maka potensi yang ada didalam dirinya akan terhambat. Sebaliknya jika remaja memiliki kepercayaan diri yang tinggi maka potensi didalam diri remaja tersebut dapat tereksplorasi dengan baik. Penelitian ini menggunakan pendekatan kuantitatif dengan rancangan eksperimen murni. Desain penelitian yang digunakan adalah pretest and posttest control group design. Hasil pretest menunjukkan bahwa seluruh siswa yang termasuk ke dalam kelompok eksperimen yang terdiri dari 2 orang dengan skor yang masuk pada kategori sangat rendah dan 4 orang dengan kategori rendah. Anggota kelompok yang memiliki skor rendah dan sangat rendah, kemudian diberi intervensi berupa konseling ringkas berfokus solusi untuk meningkatkan percaya diri. Keberhasilan pelaksanaan konseling ringkas berfokus solusi yang dilakukan oleh peneliti didukung oleh beberapa hal, diantaranya terbinanya hubungan baik antara peneliti dan konseli selama masa konseling. Dapat disimpulkan bahwa konseling ringkas berfokus solusi atau solution focused brief therapy efektif untuk meningkatkan rasa percaya diri remaja.
\end{abstract}

Kata Kunci: Solution Focused Brief Therapy; Percaya Diri; Remaja.

\section{PENDAHULUAN}

Remaja didefinisikan sebagai tahap perkembangan transisi yang membawa individu dari masa kanak-kanak ke masa dewasa, yang ditandai dengan perubahan fisik karena pubertas serta perubahan kognitif dan sosial. Santrock (2007:20) mengemukakan bahwa masa remaja adalah periode transisi perkembangan antara masa kanak-kanak dan masa dewasa, yang melibatkan perubahan-perubahan biologis, kognitif, dan sosioemosional. Menurut Stanley Hall masa remaja merupakan masa badai dan tekanan (storm and stress).

Kepercayaan diri yang memadai diperlukan untuk melaksanakan tugas perkembangan pada remaja. Dilihat dari sudut pandang perkembangan, pada usia remaja sangat rentan dengan rasa percaya diri yang dia miliki. Rasa percaya diri yang dimiliki remaja akan 
mempengaruhi pengembangan potensi yang dimilikinya apabila remaja tersebut memiliki rasa percaya diri yang rendah maka potensi yang ada didalam dirinya akan terhambat. Sebaliknya jika remaja memiliki kepercayaan diri yang tinggi maka potensi didalam diri remaja tersebut dapat tereksplorasi dengan baik.

Pada proses berinteraksi dengan lingkungan sosial, percaya diri atau self-confidence pada remaja akan sangat berperan dalam pembentukan pribadi yang kuat, sehat dan memiliki kemampuan untuk menentukan pilihan, dan tidak mudah terpengaruh godaan dari teman sebaya mereka sendiri. Masters and Johnson dalam Atkinson (tanpa tahun, ed. Ke 11) mengatakan bahwa rasa percaya diri berpengaruh terhadap sikap seseorang pada status dia sebagai remaja. Pada masa remaja (usia 12-18), biasanya masih ada remaja yang mengalami penurunan rasa percaya diri. Masters mengemukakan, penurunan ini disebabkan karena perubahan fisik yang begitu cepat dan tidak beraturan pada diri kanak- kanak yang beranjak remaja, sementara itu remaja belum memiliki identitas diri yang jelas, sehingga "bagaimana penampilan saya, bagaimana orang lain melihat saya", seringkali disepadankan dengan "siapa saya".

Hal ini juga masih ditambah lagi dengan kaitan yang erat antara kemenarikan diri segi fisik dengan penerimaan sosial, yang semakin membuat remaja merasa tidak percaya diri. Karena di dalam masyarakat bergulir sebuah anggapan bahwa semakin cantik, tampan, pintar, macho, feminine, maskulin, seksi, rajin, dan sebagainya maka akan semakin besar pula penerimaan lingkungan pergaulannya. Mulai dari cara berbicara, berpakaian, sampai bertingkah laku, remaja tidak hanya mengikuti apa yang diajarkan dan diarahkan oleh orang tua di rumah, namun juga memperhatikan dan mengikuti apa yang dilakukan oleh temanteman sebayanya (Rini, 2002).

Dalam berhubungan dengan orang lain atau dalam proses interaksi, selalu terdapat aksi dan reaksi. Reaksi ini sebenarnya banyak memberikan pengaruh kepada diri seseorang karena setiap orang tentu berharap reaksi yang positif dalam berinteraksi, misalnya dengan reaksi itu merasa bangga dan puas. Namun jika reaksinya negatif, maka akan menghasilkan konsep diri yang negative pada diri seseorang, sehingga dengan reaksi itu dia merasa tidak senang dan kecewa. Reaksi itu pula yang dapat membentuk konsep diri menjadi kurang percaya diri (Darajat, 1983).

Seperti yang dikatakan oleh Angelis (2005, hlm. 20) "rendah diri, rasa malu, rasa takut melakukan sesuatu, frustrasi, perasaan cemas atau bahkan sikap agresif merupakan indikator dari kurang atau tidak adanya kepercayaan diri”. Gejala tidak percaya diri ini umumnya dianggap sebagai gangguan ringan karena tidak menimbulkan masalah besar. Disadari atau tidak, sebagian besar orang ternyata mengalami gejala tidak percaya diri seperti ini. Sikap seseorang yang menunjukkan dirinya tidak percaya diri, antara lain di dalam berbuat sesuatu, terutama dalam melakukan sesuatu yang penting dan penuh tantangan, selalu dihinggapi keraguan-raguan, mudah cemas, tidak yakin, cenderung menghindar, tidak punya inisiatif, mudah patah semangat, tidak berani tampil di depan orang banyak, dan gejala kejiwaan lainnya yang menghambatnya untuk melakukan sesuatu. 
Menurut Perry (2005), kepercayaan diri berarti merasa positif tentang apa yang bisa dilakukan dan tidak mengkhawatirkan apa yang tidak bisa dilakukan, tapi memiliki kemauan belajar. Kepercayaan diri adalah pelumas yang memperlancar roda hubungan antara kemampuan yaitu bakat, keahlian dan potensi, dan cara memanfaatkannya. Seseorang yang selalu beranggapan bahwa dirinya tidak mempunyai kemampuan, merasa dirinya tidak berharga, merasa dirinya paling bodoh dan sebagainya merupakan gambaran dari orang yang mempunyai rasa percaya diri yang rendah. Hal ini dapat dimanifestasikan dalam bentuk tingkah laku yang kurag wajar atau menyimpang,misalnya rendah diri, terisolir, prestasi belajar rendah dan kurang percaya diri. Timbulnya masalah tersebut bersumber dari kepribadiannya yakni oleh konsep dirinya yang negative dan kepercayaan dirinya yang rendah sehingga akan berpengaruh pada penyesuaian dirinya yang juga rendah (Atmoko, 1991, hlm. 82).

Individu yang memiliki rasa kurang percaya diri akan selalu takut dan ragu untuk melangkah atau bertindak, berpendapat maupun berinteraksi, baik dalam kelompok maupun masyarakat. Seperti pendapat yang dikemukakan oleh Kartono dan Andrani (1987, hlm. 74) yang menjelaskan bahwa: "perasaan-perasaan kurang percaya diri ini sering mematahkan semangat anak, merasa tidak sanggup berdiri diatas kaki sendiri”. Lebih lanjut dijelaskan bahwa dengan keadaan seperti ini maka hilanglah ambisi untuk menciptakan perjuangan hidup, karena ia dibayangi oleh perasaan tidak mampu (Kartono, 1989).

Kepercayaan diri individu perlu ditingkatkan, karena dengan percaya diri seseorang akan mengenal dirinya serta mengenal potensi yang dimilikinya. Seseorang yang tidak memiliki kepercayaan diri, ia tidak dapat bersosialisasi dengan orang lain. Kepercayaan diri yang rendah salah satunya karena individu tidak dapat menyesuaikan diri dengan lingkungan atau individu yang kurang memiliki kemampuan dan keterampilan dalam berinteraksi dengan orang lain. Kepercayaan diri yang rendah ini dapat mengakibatkan rasa pesimis, apatis, menarik diri dalam pergaulan, tidak berani mengemukakan ide atau perasaannya, serta tidak berani bertindak ataupun mengambil inisiatif, dengan demikian kurangnya kepercayaan diri dapat menyebabkan potensi manusia tidak dapat berkembang secara optimal (Darajat, 1980).

Pada artikel yang dimuat dalam Blog Problem Perilaku Anak (2011), masalah kepercayaan diri adalah masalah yang paling sering mengganggu pada masa remaja. Remaja yang mempunyai masalah kepercayaan diri mudah merasa tidak puas dengan keadaan diri mereka, sadar diri berlebihan dan terlalu peka terhadap komentar orang lain. Sekalipun masalah kepercayaan diri ini merupakan masalah yang wajar dialami saat melalui masa remaja, ada baiknya jika orang tua melakukan upaya-upaya kecil untuk membantu anak segera mendapatkan kembali kepercayaan dirinya.

Beberapa permasalahan psikis dan sosial remaja diantaranya penyimpangan perilaku seperti merokok, penyalahgunaan alkohol, narkotika, dan zat adiktif lainnya, prostitusi, berkunjung ke diskotek, hamil sebelum pernikahan, dan aborsi (Yusuf, 2009, hlm. 31-32). Berdasarkan survei Komnas Anak, sebanyak 50 persen remaja perokok merasa lebih percaya diri karena merokok. Santrock (2007, hlm. 446) menemukan beberapa alasan mengapa 
remaja mengkonsumsi narkoba yaitu karena ingin tahu, untuk meningkatkan kepercayaan diri, solidaritas, adaptasi dengan lingkungan, maupun untuk kompensasi. beberapa permasalahan remaja berawal dari kurangnya kepercayaan diri serta perlunya peningkatan kepercayaan diri pada remaja. Kepercayaan diri menurut Lauster (2008, hlm. 4) merupakan suatu sikap atau keyakinan atas kemampuan diri sendiri sehingga dalam tindakantindakannya tidak terlalu cemas, merasa bebas untuk melakukan hal-hal yang sesuai keinginan dan tanggung jawab atas perbuatannya, sopan dalam berinteraksi dengan orang lain, memiliki dorongan prestasi serta dapat mengenal kelebihan dan kekurangan diri sendiri. Lauster menggambarkan bahwa orang yang mempunyai kepercayaan diri memiliki ciri-ciri tidak mementingkan diri sendiri (toleransi), tidak membutuhkan dorongan orang lain, optimis dan gembira.

Beberapa ciri atau karakteristik individu yang kurang percaya diri, di antaranya adalah: berusaha menunjukkan sikap konformis, semata-mata demi mendapatkan pengakuan dan penerimaan kelompok; menyimpan rasa takut/kekhawatiran terhadap penolakan; sulit menerima realita diri (terlebih menerima kekurangan diri) dan memandang rendah kemampuan diri sendiri namun di lain pihak memasang harapan yang tidak realistik terhadap diri sendiri, pesimis, mudah menilai segala sesuatu dari sisi negatif; takut gagal, sehingga menghindari segala resiko dan tidak berani memasang target untuk berhasil; cenderung menolak pujian yang ditujukan secara tulus (karena undervalue diri sendiri); selalu menempatkan/memposisikan diri sebagai yang terakhir, karena menilai dirinya tidak mampu; mempunyai external locus of control (mudah menyerah pada nasib, sangat tergantung pada keadaan dan pengakuan/penerimaan serta bantuan orang lain) (Fatimah 2010, hlm. 150).

Pendekatan konseling yang memperhatikan aspek keefektifan dan efisiensi dalam mewujudkan perubahan merupakan suatu pendekatan yang berangkat dari landasan filosofis postmodern dan konstruktivisme sosial. Postmodern berkaitan dengan gerakan atau perspektif yang menolak pandangan-pandangan modern. Dasar pandangan modern adalah meyakini adanya realitas objektif yang teramati dan diketahui secara sistematis. Individu datang ke dalam sebuah proses konseling karena mereka meyakini telah menyimpang terlalu jauh dari beberapa norma objektif atau dengan istilah patologis. Pandangan modern tersebut bertentangan dengan pandangan postmoderen. Postmoderen lebih mempercayai bahwasanya realitas dikonstruk faktor bahasa dan budaya. Landasan filosofis yang kedua adalah konstruktivisme sosial. Konstruktivisme sosial memiliki arti bahwa pemaknaan individu dibuat atau diciptakan dalam konteks sosial (Locke, 2001).

Keyakinan yang dimiliki individu mengkonstruk pengalaman hidupnya berupa bahasa menjadi sebuah paradigma mendasar konstruksionisme sosial. Permasalahan yang dihadapi individu dimediasi melalui bahasa yang digunakan untuk membingkai pengalamannya. Konstruktivisme berfokus pada pandangan hidup yang dibangun dan dipelihara dalam bentuk Bahasa. Pendekatan konseling yang berawal dari filosofi postmodern dan konstruktivisme sosial tidak mendukung atau menggunakan model psikopatologis. Diagnosis terhadap individu dipandang sebagai suatu prosedur yang tidak membantu. 
Salah satu pendekatan konseling yang berasal dari filosofi postmoderen dan konstrustivisme sosial adalah Solution Focused Brief Therapy (Konseling Ringkas Berfokus Solusi). Solution focused brief therapy (konseling ringkas berfokus solusi) merupakan pendekatan konseling yang menekankan pada masa sekarang dan masa depan, dengan mengabaikan masa lalu. Solution focused brief therapy menitikberatkan pada percakapan solusi dan langsung mengarah pada langkah apa yang akan dilakukan konseli di kemudian hari dengan permasalahan yang melekat dalam hidupnya, sehingga sesi menjadi ringkas dan singkat. Konseling ini didasarkan pada asumsi bahwa setiap individu itu ulet, banyak akal, cakap dan memiliki kemampuan untuk mengkonstruk solusi yang dapat mengubah kehidupan mereka (Corey, 2009, hlm. 378).

Percaya diri bukan merupakan sesuatu yang bersifat bawaan tetapi merupakan sesuatu yang terbentuk dari interaksi. Untuk menumbuhkan percaya diri diperlukan situasi yang memberikan kesempatan untuk berkompetisi, karena seseorang belajar tentang dirinya sendiri melalui interaksi langsung dan komparasi sosial. Dari interaksi langsung dengan orang lain akan diperoleh informasi tentang diri dan dengan melakukan komparasi sosial seseorang dapat menilai dirinya sendiri bila dibandingkan dengan orang lain. Seeorang akan dapat memahami diri sendiri dan akan tahu siapa dirinya yang kemudian akan berkembang menjadi percaya diri atau self-confidence.

Menurut Corey (2012, hlm. 425) solution focused brief therapy memandang manusia sebagai pribadi yang berkompeten, mampu menyusun solusi-solusi yang dapat mengarahkan tujuan-tujuan hidupnya. Menurut Davis \& Osborn (dalam Lines, 2006), konseling ringkas (brief therapy) bukan suatu konseling yang cepat selesai, akan tetapi konseling dirancang untuk fokus pada sebuah rencana intervensi sesi ringkas yang bertujuan untuk membantu konseli mengatur tentang apa yang harus dilakukannya.

Beberapa teknik yang dapat digunakan dalam solution focused brief therapy menurut Birdsall dan Miller (dalam Brasher, 2009, hlm. 22) antara lain: a) coping question, b) exception-finding question, c) the miracle question, d) scaling question, dan e) taskdevelopment question. Melalui teknik yang terdapat pada solution focused brief therapy dapat digunakan oleh konselor untuk membantu mengatasi permasalahan siswa, salah satunya rasa percaya diri siswa yang rendah.

Setiap siswa memiliki rasa percaya diri, namun tingkat percaya diri setiap siswa berbeda. Siswa yang memiliki rasa percaya diri yang tinggi akan merasa lebih yakin dengan kemampuan yang dimilikinya, hal ini menjadikan siswa mampu berfikir lebih positif, optimis dan berperilaku positif, seperti mengerjakan ujian tanpa mencontek karena yakin dengan kemampuan yang dimilikinya, mampu berkomunikasi dengan baik dengan orangorang disekitarnya baik itu teman, guru maupun orang tua, serta mampu mengoptimalkan potensi dan bakat yang dimilikinya tanpa rasa ragu atau malu, sedangkan bagi siswa yang kurang memiliki rasa percaya diri akan muncul banyak keraguan dan ketakutan akan kegagalan yang mengakibatkan siswa berperilaku menyimpang seperti mencontek pada saat ujian karena merasa tidak yakin dengan kemampuan diri yang dimilikinya, selalu merasa tidak puas dengan diri sendiri, pesimis, kurang mampu berkomunikasi dalam mengutarakan 
keinginan dan pendapat sendiri kepada orang lain, merasa ragu dan takut untuk mengembangkan bakat yang dimilikinya karena merasa malu apabila gagal.

Penelitian ini menitikberatkan pada bagaimana siswa mampu meningkatkan rasa percaya diri mereka dengan menggunakan teknik-teknik yang ada pada solution focused brief therapy. Pendekatan ini tergolong ringkas, ringkas disini diartikan sebagai pelaksanaan konseling yang berfokus kepada tujuan dan keinginan konseli ke depannya tanpa harus melihat dan membahas permasalahan sebelumnya. Hasil evaluasi yang dilakukan oleh Franklin, Moore dan Hopson (2008) juga menunjukkan bahwa solution focused brief therapy efektif dalam menangani anak yang mempunyai problem perilaku di kelas atau seting sekolah.

\section{METODE PENELITIAN}

Penelitian ini menggunakan pendekatan kuantitatif dengan rancangan eksperimen murni. Desain penelitian yang digunakan adalah pretest and posttest control group design. Pemilihan desain penelitian ini didasarkan atas pertimbangan-pertimbangan bahwa: 1) rancangan penelitian ini merupakan yang paling tepat diantara jenis-jenis eksperimen lain dan dapat diaplikasikan dalam penelitian-penelitian bidang pendidikan maupun psikologi; 2) rancangan penelitian ini paling tepat karena menempatkan subjek penelitian secara acak (random); dan 3) rancangan penenelitian ini merupakan rancangan penelitian yang tepat untuk menguji hipotesis karena dapat memberikan pengendalian yang memadai sehingga variabel bebas bisa dinilai dengan tepat.

Ada dua kelas yang dijadikan sebagai subjek penelitian, kedua kelas tersebut mendapatkan skala percaya diri untuk mengetahui siswa dengan percaya diri yang sangat rendah dan rendah. Selanjutnya, dipilih 12 siswa yang memiliki percaya diri sangat rendah dan rendah lalu dibagi menjadi dua kelompok yakni:

Tabel 1 Distribusi Sampel Penelitian

\begin{tabular}{ccccc}
\hline Kelompok & Jenis Kelamin & N & Total & Kelas \\
\hline Eksperimen (Konseling & Laki-laki & 4 & 6 & 7.5 \\
$\begin{array}{c}\text { Kelompok Ringkas Berfokus } \\
\text { Solusi) }\end{array}$ & Perempuan & 2 & & \\
\hline Kontrol (Konseling as usual) & Perempuan & 6 & 6 & 7.4 \\
\hline
\end{tabular}

\section{HASIL DAN PEMBAHASAN Hasil Penelitian}

Hasil penelitian berdasarkan hasil pengukuran percaya diri siswa dengan menggunakan skala percaya diri, diperoleh hasil sebagai berikut: 
Tabel 2. Rekapitulasi Skor Hasil Skala Percaya Diri

\begin{tabular}{cccccc}
\hline \multicolumn{2}{c}{ Kelompok } & \multicolumn{2}{c}{ Skor Kelompok } & \multicolumn{2}{c}{ Kategori } \\
\hline Eksperimen & Kontrol & Eksperimen & Kontrol & Eksperimen & Kontrol \\
\hline HF & BE & 133 & 130 & Rendah & Rendah \\
\hline VF & LE & 132 & 128 & Rendah & Rendah \\
\hline RN & AA & 132 & 125 & Rendah & Rendah \\
\hline MF & VA & 128 & 122 & Rendah & Sangat Rendah \\
\hline LB & MB & 124 & 119 & Sangat Rendah & Sangat Rendah \\
\hline ZD & DA & 118 & 117 & Sangat Rendah & Sangat Rendah \\
\hline
\end{tabular}

Hasil pre-test menunjukkan bahwa seluruh siswa yang termasuk ke dalam kelompok eksperimen yang terdiri dari 2 orang dengan skor yang masuk pada kategori sangat rendah dan 4 orang dengan kategori rendah. Anggota kelompok yang memiliki skor rendah dan sangat rendah, kemudian diberi intervensi berupa konseling ringkas berfokus solusi untuk meningkatkan percaya diri. Intervensi konseling ringkas berfokus solusi dilakukan sebanyak enam pertemuan, termasuk pra-konseling yakni dengan mengadakan Pre-test pada pertemuan pertama dan diakhiri dengan dilaksanakannya Post-test pada pertemuan keenam. Setelah pelaksanaan intervensi, terdapat perubahan pada diri siswa yang termasuk ke dalam kelompok eksperimen. Perubahan tersebut dapat dilihat dari hasil pengukuran yang dilakukan dengan menggunakan skala percaya diri yang dilakukan setelah pemberian intervensi (post-test). Terdapat peningkatan skor dari siswa yang telah diberi intervensi konseling kelompok ringkas berfokus solusi, skor awal (pre-test) termasuk ke dalam kategori kelompok rendah dan setelah diberi intervensi (post-test) skor yang diperoleh siswa meningkat dan tergolong kategori tinggi.

Table 3. Hasil Prestest dan Posttest Kelompok Eksperimen

\begin{tabular}{c|cccc}
\hline Siswa & Skor Pre-test & Kategori & Skor Post-test & Kategori \\
\hline HF & 133 & Rendah & 172 & Tinggi \\
VF & 132 & Rendah & 173 & Tinggi \\
RN & 132 & Rendah & 163 & Tinggi \\
MF & 128 & Rendah & 160 & Tinggi \\
LB & 124 & Sangat Rendah & 162 & Tinggi \\
ZD & 118 & Sangat Rendah & 158 & Tinggi \\
\hline
\end{tabular}

Peneliti memberikan intervensi konseling ringkas berfokus solusi kepada konseli sebanyak empat sesi, setiap sesi berdurasi 40-50 menit. Sebelum pelaksanaan konseling ringkas berfokus solusi, peneliti meminta kesediaan konseli yang terpilih untuk melaksanakan konseling dari sesi awal sampai akhir. Setelah memiliki kesepakatan dengan konseli, peneliti melakukan perjanjian secara tertulis yang dikuatkan dengan penandatanganan peraturan yang harus ditaati selama mengikuti kegiatan konseling ringkas berfokus solusi.

Pada sesi pertama konseling ringkas berfokus solusi, konseli yang tergabung dalam 
kelompok eksperimen diberikan penjelasan mengenai percaya diri, dan aspek apa saja yang terkait dengan percaya diri. Kegiatan konseling ringkas berfokus solusi dirasa akan lebih mudah dilaksanakan apabila konseli sudah memahami makna percaya diri. Peneliti memberikan pertanyaan skala (scaling question) di setiap sesi kepada konseli untuk memantau dan mengetahui sejauh mana tingkat percaya diri dari masing-masing siswa. Setelah itu peneliti memberikan pertanyaan keajaiban (miracle question), pada pertanyaan keajaiban ini konseli diminta untuk membayangkan saat-saat dimana segala hambatan yang selama ini mereka miliki untuk percaya diri hilang, dan apa yang akan mereka lakukan.

Sesi kedua, peneliti memberikan teknik pertanyaan pengecualian (exceptional question) kepada konseli. Setiap koanggota kelompok diminta untuk menuliskan keadaan atau kondisi yang berbeda dimana mereka bisa memiliki rasa percaya diri yang tinggi. Sesi selanjutnya, konseli diminta untuk mengidentifikasi hambatan atau kendala yang muncul saat mereka ingin mewujudkan tujuan yang ingin diraih. Setelah mengidentifikasi hambatan yang mungkin akan muncul, konseli diminta untuk memikirkan strategi atau langkah apa yang akan mereka ambil untuk menghadapi hambatan tersebut.

Pada setiap akhir pertemuan, konseli diminta untuk menulis jurnal refleksi diri, yang berisi mengenai pengalaman, hambatan, dan harapan dalam kegiatan konseling kelompok tersebut. Dari berbagai teknik yang digunakan, pertanyaan berskala dirasa paling membantu konseli dalam mengevaluasi percaya diri yang dimilikinya. Pada setiap sesi, konseli bercerita mengenai percaya dirinya, apakah mengalami peningkatan atau penurunan, dan itu menggunakan pertanyaan berskala (scaling question) tersebut. Seperti yang diungkapkan Corey (2009, hlm. 311) di dalam bukunya bahwa pertanyaan berskala (scaling question) digunakan untuk mempermudah terapis melihat perubahan pengalaman konseli yang tidak dapat diamati dengan mudah, seperti perasaan, suasana hati ( $m o o d)$, atau komunikasi.

Keberhasilan pelaksanaan konseling ringkas berfokus solusi yang dilakukan oleh peneliti didukung oleh beberapa hal, diantaranya terbinanya hubungan baik antara peneliti dan konseli selama masa konseling. Peneliti menunjukkan sikap yang hangat, terbuka, peduli, empati dan perhatian kepada konseli sehingga terciptalah suasana yang akrab dan hangat yang membantu proses perubahan pada diri konseli. Disamping itu, keberhasilan konseling kelompok ringkas berfokus solusi tidak terlepas dari faktor konseli itu sendiri. Adanya keinginan dari konseli sendiri untuk berubah menjadi pribadi yang lebih baik membantu kesuksesan konseling. Konseli yang ingin berubah harus menyadari bahwa dirinya membutuhkan percaya diri, sebagai penunjang kesuksesannya sekarang dan di kemudian hari.

Terdapat beberapa penelitian yang dilakukan di Indonesia terkait dengan konseling ringkas berfokus solusi. Berdasarkan penelitian yang dilakukan Mulawarman (2010), menunjukkan bahwa konseling ringkas berfokus terapi dapat meningkatkan harga diri (selfesteem) siswa SMA. Pada penelitian lainnya Dahlan (2011) menunjukkan bahwa secara spesifik konseling ringkas berfokus terapi mampu meningkatkan semua aspek-aspek daya psikologis yakni kemampuan interpersonal (pemahaman diri, pengarahan diri, dan penghargaan diri) serta kemampuan interpersonal (peka terhadap diri sendiri dan orang lain, 
nyaman dengan diri sendiri dan orang lain, membiarkan orang lain bebas, ekspektasi yang realistis tentang diri sendiri dan orang lain, dan perlindungan diri dalam situasi interpersonal). Penelitian Ummah (2012) menunjukkan bahwa Konseling Kelompok Ringkas Berfokus Solusi dapat meningkatkan efikasi diri akademik siswa SMP. Selanjutnya pada penelitian Fitriyah (2014) menunjukkan bahwa Konseling Kelompok Ringkas Berfokus Solusi efektif mereduksi perilaku agresif pada semua aspek perilaku agresif yakni, agresi fisik, agresi verbal, kemarahan, dan permusuhan.

\section{Pembahasan}

Weishaar (dalam Corey, 2009, hlm. 375) menjelaskan bahwa secara filosofis, solution focused brief therapy didasari oleh suatu pandangan bahwa sejatinya kebenaran dan realitas bukanlah suatu yang bersifat mutlak namun realitas dan kebenaran dapat dikonstruksikan. Pada dasarnya semua pengetahuan bersifat relatif karena selalu ditentukan oleh konstruk, budaya, bahasa atau teori yang kita terapkan pada suatu fenomena tertentu. Menurut konstruksionis sosial, realitas didasarkan pada penggunaan bahasa dan umumnya merupakan fungsi situasi dimana seseorang berada.

Dalam memahami solution focused brief therapy tidak dapat mengabaikan landasan filosofinya. Landasan tersebut yaitu postmodern dan konstruktivisme sosial. Postmodern berkaitan dengan gerakan atau perspektif yang memposisikan untuk menolak pandangan modern. Dasar pandangan modern adalah meyakini adanya realitas objektif yang teramati dan diketahui secara sistematis. Individu yang mengikuti proses konseling merasa dirinya sudah menyimpang dari nilai dan norma objektif, atau biasa disebut patologis. Pandangan moderen tersebut bertentangan dengan pandangan postmodern, yang percaya bahwa kebenaran bersifat subjektif bukan objektif. Postmodern lebih mempercayai bahwa realitas dikonstruk faktor bahasa dan budaya, serta tidak adanya kategori yang menandai suatu kondisi (realita).

Landasan kedua dalam solution focused brief therapy yaitu konstruktivisme sosial. Corey (2009) menjelaskan bahwa konstruktivisme sosial memiliki arti bahwa pemaknaan setiap individu didasarkan pada konteks sosial yang dibuat dan diciptakannya. Orang-orang konstruktivisme sosial percaya bahwa realitas didasarkan pada penggunaan bahasa dan umumnya merupakan fungsi situasi dimana orang tersebut hidup. Konstruktivisme sosial percaya bahwa realita budaya, seperti politik, religi, keluarga, dan pengetahuan berpengaruh terhadap pengalaman masing-masing individu.

Menurut O'Connell (2004, hlm. 1) solution focused brief therapy merupakan bentuk konseling ringkas yang dibangun berdasarkan kemampuan yang dimiliki konseli. Konseling ini bertujuan untuk membantu konseli mencapai hasil yang diinginkan dengan membangkitkan dan membangun solusi dari masalahnya. Sedangkan menurut Jackson \& McKergow (2002, hlm. 1) solution focused brief therapy merupakan pendekatan yang sangat kuat, praktis, dan terbukti dapat mengubah positif individu, kelompok, dan organisasi. Konseling ini berfokus pada solusi, menolak pendekatan-pendekatan konvensional yang memberikan asumsi secara luas bahwa cara terbaik dalam menyelesaikan masalah adalah 
fokus terhadap masalahnya.

Corey (2012, hlm. 425) menyatakan bahwa solution focused brief therapy merupakan pendekatan yang berfokus pada masa depan, berorientasi tujuan. Pendekatan ini bergeser fokusnya dari penyelesaian masalah kemudian menekankan pada solusinya. Pendekatan ini menekankan kekuatan dan resiliensi individu dengan mengesampingkan masalahnya dan berpusat pada solusi. Pendekatan ini berasumsi positif bahwa setiap individu berakal dan berkompeten, serta memiliki kemampuan untuk membangun solusi yang dapat mengubah arah hidupnya.

De Shazer (dalam Corey, 2009, hlm. 378) menyatakan bahwa tidak penting mengetahui penyebab suatu masalah untuk dapat menyelesaikannya dan tidak ada hubungan antara masalah dan solusi. Mengumpulkan informasi tentang suatu masalah tidaklah penting untuk terjadinya suatu perubahan. Jika mengetahui dan memahami masalah bukanlah sesuatu yang penting, maka mencari solusi yang terbaik itulah yang benar-benar penting. Solusi yang benar menurut satu orang belum tentu benar terhadap orang lain. Di dalam konseling ini, konseli memilih tujuan-tujuan yang ingin dicapai, dan diberikan sedikit saja perhatian terhadap diagnosis, pembicaraan tentang masa lalu, atau eksplorasi masalah (Berg \& Miller, 1992; De Shazer \& Dolan, 2007; Gingerich \& Eisengart, 2000; O’Hanlon \& Weiner-Davis, 2003).

Berdasarkan penjelasan beberapa ahli di atas, maka dapat disimpulkan bahwa konseling kelompok ringkas berfokus solusi merupakan pendekatan konseling yang mengesampingkan masalah, namun lebih menekankan pada pencarian solusi. Konseling ini juga memandang bahwa setiap individu memiliki kemampuan atau kompetensi dalam mencari dan menentukan solusi terbaik yang nantinya dapat digunakan dalam menentukan hidupnya. Walter \& Peller (dalam Corey, 2012, hlm. 430) menjelaskan ada empat tahapan konseling kelompok ringkas berfokus solusi sebagai berikut:

a. Mencari tahu apa yang anggota kelompok inginkan daripada mencari apa yang tidak diinginkan.

b. Tidak mencari patologi dan tidak mencoba untuk mengurangi kemampuan anggota dengan memberi label diagnostik. Sebaliknya, mencari apa yang anggota lakukan yang sudah bekerja dan mendorong anggota untuk terus ke arah itu.

c. Jika apa yang anggota lakukan tidak bekerja, mendorong anggota untuk bereksperimen dengan melakukan sesuatu yang berbeda.

d. Menjaga konseling berlangsung ringkas dengan mendekati setiap sesi seolah-olah itu adalah sesi terakhir.

Beberapa teknik yang digunakan dalam konseling kelompok ringkas berfokus solusi antara lain (Corey, 2012, hlm 433) sebagai berikut.

a. Perubahan pra-sesi (Presession Change), salah satu ciri khas pendekatan konseling kelompok ringkas berfokus solusi adalah perhatian yang berfokus pada solusi untuk perubahan yang sudah muncul sebelum sesi pertama. Solusi berfokus pada perubahan alami dan terjadinya konstan yang menjadi harapan konseli karena mereka berjuang 
untuk mengubah apa yang awalnya tampak sebagai masalah besar yang mereka takuti. Konselor mengajukan pertanyaan "sejak Anda dipanggil, sampai kita bertemu pada pertemuan pertama ini, ada perubahan apa yang Anda dapatkan?”

b. Pertanyaan, pertanyaan menjadi alat komunikasi dan intervensi utama. Pemimpin kelompok menggunakan pertanyaan sebagai cara untuk lebih memahami pengalaman anggota kelompok bukan hanya untuk mengumpulkan informasi. Pertanyaan diminta dari posisi hormat, keingintahuan yang tulus, minat yang tulus, dan keterbukaan. Jawaban anggota kelompok memberikan informasi yang merangsang kepentingan pemimpin, dan pertanyaan lain berlangsung dari setiap jawaban yang diberikan. Anggota kelompok lainnya didorong untuk merespon bersama dengan pemimpin kelompok untuk mempromosikan kolaborasi kelompok. Menciptakan proses kelompok kolaboratif sangat penting untuk keberhasilan kelompok.

c. Pertanyaan pengecualian (Exception Question), pertanyaan pengecualian digunakan untuk mengarahkan konseli ketika masalah yang dialaminya tersebut tidak ada. Pengecualian merupakan pengalaman masa lalu dalam kehidupan konseli ketika dia mempunyai beberapa harapan masalah tersebut terjadi, masalah tersebut tidak semuanya kuat dan tidak selamanya ada.

d. Pertanyaan keajaiban (Miracle Question), konselor meminta konseli untuk berimajinasi bahwa suatu keajaiban akan terjadi di masa depan. Konseli didorong untuk membiarkan dirinya bermimpi tentang suatu cara untuk mengidentifikasi perubahan yang mereka inginkan. Pertanyaan keajaiban mempunyai fokus pada masa depan dimana konseli menginginkan kehidupan yangberbeda yang tidak berkutat pada masa lalu dan sekarang tetapi pemuasan hidup di masa mendatang.

e. Pertanyaan berskala (Scaling Question), pertanyaan skala memberikan kemungkinan pada konseli untuk lebih memperhatikan apa yang telah mereka lakukan, dan bagaimana mereka mengambil langkah yang akan mengarahkan pada perubahan yang mereka harapkan.

f. Rumusan tugas sesi pertama (Formula First Session Task), Formula First Session Task adalah suatu format tugas yang diberikan konselor kepada konseli untuk diselesaikan antara sesi pertama dan sesi kedua. Konselor berkata, "diantara hari ini dan pertemuan kita selanjutnya saya berharap Anda dapat mengamati, sehingga Anda dapat menjelaskan kepada saya pada pertemuan mendatang tentang apa yang terjadi dalam kegiatan belajar atau prestasi akademik Anda". Pada sesi kedua, konseli dapat ditanya tentang apa yang telah mereka amati dan apa yang mereka inginkan dapat terjadi di masa yang akan datang.

g. Umpan balik (Feedback), konselor pada umumnya mengambil waktu 5-10 menit pada akhir setiap sesi untuk menyusun ringkasan atau kesimpulan konseling. Konselor memformulasikan umpan balik yang akan diberikan pada konseli. Pemberian umpan balik memiliki tiga hal yaitu sebagai pujian, jembatan penghubung, dan pemberian tugas. 
Menurut Lindenfield (1997, hlm. 3) "bahwa orang yang percaya diri ialah orang yang merasa puas dengan dirinya". Kepercayaan diri merupakan suatu keyakinan dalam jiwa manusia bahwa tantangan hidup apapun harus dihadapi dengan berbuat sesuatu. Kepercayaan diri lahir dari kesadaran jika seorang individu memutuskan untuk melakukan sesuatu, sesuatu itu pula yang harus dilakukan. Kepercayaan diri itu akan datang dari kesadaran seorang individu bahwa individu tersebut memiliki tekad untuk melakukan apapun, sampai tujuan yang diinginkan tercapai.

Perry berpendapat $(2005, \mathrm{hlm} .1)$ kepercayaan diri memberikan kemampuan individu untuk mengatasi tantangan baru, meyakini diri sendiri dalam situasi sulit, melewati batasan yang menghambat, menyelesaikan hal yang belum pernah dilakukan, mengeluarkan bakat serta kemampuan sepenuhnya, dan tidak mengkhawatirkan kegagalan. Ciri individu yang percaya diri adalah lebih fokus pada apa yang bisa dilakukan dan hasil positif yang akan diraih, bukan apa yang tidak bisa dilakukan dan apa yang mungkin salah.

Dapat disimpulkan bahwa percaya diri adalah keyakinan dan percaya bahwa setiap individu memiliki kelebihan dan kemampuan dalam menangani segala sesuatu dalam hidupnya. Dengan adanya rasa percaya diri individu akan mampu mengoptimalkan potensi yang dimilikinya tanpa takut dan ragu untuk mencoba, mampu menjadi individu yang lebih bertanggung jawab terhadap dirinya sendiri dan sekitarnya, mampu berfikir positif dan lebih optimis dalam menghadapi segala permasalahan yang dihadapinya. Kepercayaan diri merupakan salah satu modal utama bagi individu untuk bisa maju dan berkembang, tanpa adanya rasa percaya diri individu akan sulit untuk mencapai apa yang diinginkannya karena selalu merasa ragu dan takut untuk mencoba hal baru. Hal ini dapat menjadi penghambat bagi kemajuan individu itu sendiri.

\section{SIMPULAN}

Hasil pre-test menunjukkan bahwa siswa yang termasuk ke dalam kelompok eksperimen terdiri dari 2 orang dengan kategori sangat rendah dan 4 orang dengan kategori rendah. Anggota kelompok yang memiliki skor rendah dan sangat rendah, diberi intervensi berupa konseling ringkas berfokus solusi untuk meningkatkan percaya diri. Intervensi konseling ringkas berfokus solusi dilakukan sebanyak enam pertemuan. Setelah pelaksanaan intervensi, terdapat perubahan pada diri siswa kelompok eksperimen. Perubahan tersebut dapat dilihat dari hasil pengukuran yang dilakukan dengan menggunakan skala percaya diri yang dilakukan setelah pemberian intervensi (post-test). Terdapat peningkatan skor dari siswa yang telah diberi intervensi konseling kelompok ringkas berfokus solusi, skor awal (pre-test) termasuk ke dalam kategori kelompok rendah dan setelah diberi intervensi (posttest) skor yang diperoleh siswa meningkat dan tergolong kategori tinggi. Keberhasilan pelaksanaan konseling ringkas berfokus solusi yang dilakukan oleh peneliti didukung oleh beberapa hal, diantaranya terbinanya hubungan baik antara peneliti dan konseli selama masa konseling. Peneliti menunjukkan sikap yang hangat, terbuka, peduli, empati dan perhatian kepada konseli. Disamping itu, adanya keinginan dari konseli sendiri untuk berubah menjadi pribadi yang lebih baik membantu kesuksesan konseling. 


\section{DAFTAR PUSTAKA}

Angelis, B. D. (2005). Percaya Diri. Jakarta: Gramedia Pustaka Utama

Atkinson, R., Smith, E., Bem, D. Tanpa tahun. Introducing to Psychology, $11^{\text {th }}$.Edition.

Atmoko, A. (1991). Kepercayaan Diri (Aspek Penting Dalam Pendidikan). Majalah Pendidikan. Edisi 25 tahun XVIII.

Corey, G. (2009). Theory and Practice of Counseling and Psychotherapy. ( $8^{\text {th }}$ edition). Belmont, CA: Brooks/Cole.

Darajat, Z. (1983). Kesehatan Mental. Jakarta: Gunung Agung.

Kartono, K. (1996). Pengantar Metodologi Riset Sosial. Bandung: Mandar Maju.

Lauster, P. (2002). Tes Kepribadian. Jakarta: Bumi Aksara.

Lindenfield, G. (1997). Mendidik Anak Agar Percaya Diri. Jakarta.

Mulawarman. (2010). Penerapan Solution-Focused Brief Therapy (SFBT) Untuk Meningkatkan Harga Diri (Self-Esteem) Siswa SMA : Suatu Embedded Experimental Design. Tesis tidak diterbitkan. Malang: PPs UM.

Perry, M. (2005). Confidence Boosters : Pendongkrak kepercayaan Diri. Jakarta : Erlangga. Rini, J. (2002). Memupuk Rasa Percaya Diri. (on-line) (http://www.psychologyhelp.co./Percaya) Diakses 12 Januari 2014.

Santrock, J. W. (2007). Adolescence. New York: McGraw-Hill Companies, Inc. 